\title{
Originals
}

\section{Mechanism of Action of Insulin and Insulin Analogues}

\section{A Comparison of the Hepatic and Peripheral Effects on Glucose Turnover of Insulin, Proinsulin and Three Insulin Analogues Modified at Positions $A_{1}$ and $B_{29}$}

\author{
C. V. Tompkins, D. Brandenburg, R. H. Jones, and P. H. Sönksen \\ Department of Medicine, St Thomas' Hospital Medical School, London, England, and Deutsches Wollforschungsinstitut, Aachen, FRG
}

\begin{abstract}
Summary. A $\left[{ }^{14} \mathrm{C}\right]$-glucose tracer infusion method was used to compare the effects of insulin infusion on glucose metabolism with the effects of infusion of three semisynthetic modified insulins and of proinsulin. Insulin produced hypoglycaemia in the anaesthetised dog by decreasing hepatic glucose production and increasing peripheral glucose utilisation. Compensatory antihypoglycaemic mechanisms eventually modified these responses. $\mathrm{A}_{1}, \mathrm{~B}_{29}$-Diacetyl insulin exerted an hypoglycaemic effect entirely by stimulation of peripheral glucose uptake. $A_{1}-B_{29}$ crosslinked insulins and proinsulin produced hypoglycaemia almost entirely by decreasing hepatic glucose production and had little effect on tissue uptake. These observations suggest that insulin analogues may have actions in vivo that are qualitatively different from those of native insulin and suggest that certain analogues have a predominant action on the liver. This has important therapeutic implications concerning the development of semisynthetic insulins for clinical use.
\end{abstract}

Key words: Chemically modified insulins, gluconeogenesis, glucose turnover, insulin structure-function, proinsulin

Studies by Brandenburg et al. [1] and Freychet et al. [2] have suggested that reduced hormonal activity of chemically modified insulins may be associated with conformational changes occurring at a molecular site which interacts with the insulin receptor [3]. Using structural analogues of insulin whose metabolism [4] and biological activity $[1,2]$ have been studied, we have investigated the possibility that distinct physiological activities may be modified to differing extents by such changes. One of the major actions of insulin is to reduce blood glucose concentration by affecting both glucose utilisation in peripheral tissues and glucose production by the liver $[5,6,7,8]$. These two hypoglycaemic effects of insulin can be distinguished using an isotopic glucose turnover technique [9]. Experiments were performed in dogs to determine whether a series of chemically modified insulins and insulin itself produced hypoglycaemia by the same or by different mechanisms. Insulin action was compared with that of proinsulin and three insulin analogues modified at $\mathbf{A}_{1}$-glycine and $\mathbf{B}_{29}$-lysine.

\section{Materials and Methods}

\section{Animals}

Twenty-nine experiments were performed on ten normal greyhounds of between 28 and $35 \mathrm{~kg}$ body weight. Dogs were fed once daily and tested after an $18 \mathrm{~h}$ fast. They were anaesthetised with $30 \mathrm{mg} / \mathrm{kg}$ pentobarbitone; their temperatures were kept constant by a warming pad and they were artificially ventilated to a constant end tidal carbon dioxide concentration of $4-5 \%$. A total of $230 \mathrm{ml}$ blood per experiment was sampled from a jugular vein. This represents less than $10 \%$ of blood volume.

\section{$\left[{ }^{14} \mathrm{C}\right]$-Glucose Turnover Technique}

$\left[{ }^{14} \mathrm{C}\right]$-glucose infusion was used to estimate glucose turnover by the method of Steele et al. [9]. In all but two experiments (in which uniformly labelled glucose was used) D- $\left[1-{ }^{14} \mathrm{C}\right]$-glucose (Radiochemical Centre, Amersham, UK) was used as the tracer to allow estimation of recycling of glucose by the method of Dunn et al. [10]. The tracer was diluted in $0.154 \mathrm{mmol} / 1$ saline (containing $5 \mathrm{~g} / 1$ glucose carrier) to a radioactive concentration of $2.5 \mu \mathrm{Cl} / \mathrm{ml}$ (glucose concentration $0.3 \mathrm{mmol} / \mathrm{l}$ ). A priming dose of $10 \mu \mathrm{Ci}$, followed by a constant infusion of $0.11 \mu \mathrm{Ci} / \mathrm{min}$ was administered via a saphenous vein. Sixty minutes were allowed for equilibration of the radioactive glucose with the body glucose pool [5] before sampling was begun. 
Table 1. Comparison of serum peptide concentrations (mean \pm SEM) achieved during infusion at the same rates over four 30 minute periods

\begin{tabular}{|c|c|c|c|c|c|}
\hline & $\begin{array}{l}\text { Insulin } \\
\mathrm{nmol} / \mathrm{I}\end{array}$ & $\begin{array}{l}\text { Diacetyl insulin } \\
\mathrm{nmol} / \mathrm{l}\end{array}$ & $\begin{array}{l}\text { Dodecoyl insulin } \\
\text { nmol/1 }\end{array}$ & $\begin{array}{l}\text { Oxalyl insulin } \\
\mathrm{nmol} / 1\end{array}$ & $\begin{array}{l}\text { Proinsulin } \\
\mathrm{nmol} / \mathrm{l}\end{array}$ \\
\hline I (basal) & $0.02 \pm 0.003$ & - & - & - & - \\
\hline II & $0.12 \pm 0.01$ & $0.28 \pm 0.02$ & $0.23 \pm 0.03$ & $0.36 \pm 0.02$ & $0.17 \pm 0.02$ \\
\hline III & $0.28 \pm 0.02$ & $0.59 \pm 0.02$ & $0.59 \pm 0.06$ & $0.91 \pm 0.08$ & $0.43 \pm 0.05$ \\
\hline IV & $0.61 \pm 0.02$ & $1.25 \pm 0.02$ & $1.32 \pm 0.17$ & $1.61 \pm 0.07$ & $1.08 \pm 0.12$ \\
\hline $\mathrm{V}$ & $1.36 \pm 0.07$ & $2.50 \pm 0.16$ & $2.68 \pm 0.23$ & $2.91 \pm 0.10$ & $2.11 \pm 0.27$ \\
\hline $\begin{array}{l}\text { Concentration } \\
\text { of solution infused }\end{array}$ & $1790 \pm 30$ & $1745 \pm 31$ & $1631 \pm 84$ & $1631 \pm 52$ & $900 \pm 22$ \\
\hline
\end{tabular}

\section{Insulin and Analogue Infusions}

Four 'control' experiments were performed to assess possible effects of anaesthesia. The tracer infusion was continued for four and a half hours without insulin or analogue and blood samples were collected at ten minute intervals. Beef insulin was administered to six dogs by a priming-dose constant infusion technique [4]; the protocol is shown in Figure 1. Using a stepped infusion over four thirty min periods (designated II-V), four steady-state serum insulin concentrations (spanning the normal physiological range) were achieved. Similar studies were performed using equimolar infusion rates of (a) porcine proinsulin (Novo Company) (b) $A_{1}, B_{29}$-diacetyl insulin, (c) $A_{1}-B 29$ crosslinked dodecoyl insulin and (d) $A_{1}-B 29$ crosslinked oxalyl insulin [4]. Plasma glucose concentration was allowed to fall unchecked.

\section{Blood Sampling and Processing.}

Plasma samples were collected into fluoride-oxalate tubes. Plasma glucose was measured using a Beckman glucose analyser and $\left[{ }^{14} \mathrm{C}\right]$-glucose by a modification of the technique used by Dunn et al. [10]. Plasma was deproteinised by the Somogyi method [11], glucose was separated from ionised metabolites on an anion exchange resin (Bio-Rad AG-1-X-4), concentrated by lyophilisation and counted on an Inter-Technique liquid scintillation counter after redissolving in $200 \mu \mathrm{l}$ water plus $10 \mathrm{ml}$ BBOT (2,5-bis (5' tert-butyl-benz-oxazolyl-(2'))thiophene) scintillant. Recycling of glucose was measured on seven samples from each experiment by the method of Dunn et al. [10] which monitored $\left[{ }^{14} \mathrm{C}\right]$ appearance at position 6 in the glucose molecule.

Samples were taken during a thirty min basal period before insulin or analogue infusion (period I) and for sixty min after the end of the infusion (period VI). Serum insulin and analogue concentrations were measured by'double-antibody radioimmunoassay [4]: Beef insulin (lot B7300 prepared by Dr D Brandenburg) was used for infusion and as standard in the radioimmunoassay. The analogues were modifications of this preparation, and standards were prepared for the assay of each analogue. The antiserum used was a guinea-pig anti-insulin serum prepared in this laboratory. The insulin analogues all cross-reacted with this antibody producing parallel molar dose-response curves.

\section{Measurement}

Expired air was collected into Douglas Bags over five minute periods and the volumes were measured. The carbon dioxide concentration in the bag was measured directly using an infra-red capnograph. Carbon dioxide $(1 \mathrm{mmol})$ was trapped in a vial containing. $1 \mathrm{mmol}$ of hyamine hydroxide, scintillant was added and the sample counted. Quench corrections were made using the external standard ratio method. Expired ${ }^{14}$ Carbon dioxide over each thirty minute period was calculated as $\mathrm{dpm} / \mathrm{min}$ and $\mathrm{ex}$ pressed $\%$ infused $\left({ }^{14} \mathrm{C}\right)$-glucose. No measurements were made in five experiments.

\section{Calculations}

Rates of appearance $(\mathrm{Ra})$ and disappearance $(\mathrm{Rd})$ of glucose were calculated over thirty min periods by the method of Steele et al. [ 9 , $12]$. In order to perform calculations in the non-steady state, the glucose distribution space was taken as $20 \%$ body weight [12] and the rapidly equilibrating pool fraction was assumed to be $0.65[12$, 13]. Metabolic clearance rate (MCR) was calculated by standard techniques as described previously [14].

\section{Statistics}

Means, SD and SEM were calculated for each group of experiments at each time interval. Statistical significance was tested by Student's ' $\mathrm{t}$ ' test using either the paired test for within group comparisons or the unpaired test for comparison between analogues.

\section{Experiments on Conscious Dogs}

Animals were normally anaesthetised because of practical difficulties in restraining them for a $5 \mathrm{~h}$ period and because measurement of $\mathrm{CO}_{2}$ output would have been impossible in the conscious animal. However, in order to investigate the effects of barbiturate anaesthesia, beef insulin infusions were performed on three conscious dogs restrained in a harness. These animals were allowed free access to water. In these experiments glucose turnover was studied using a primed infusion of $\mathrm{D}-\left[2{ }^{3} \mathrm{H}\right]$ glucose into one saphenous vein $[15,16]$. Samples were taken from the other saphenous vein, the plasma was deproteinised and lyophilised to remove the tritiated water formed as the only metabolite, scintillant was added and the vials counted.

\section{Results}

Figure 1 shows mean results from insulin infusion in six anaesthetised greyhounds. The infusion produced four steady-state insulin concentrations ranging from $0.12 \pm 0.01$ to $1.36 \pm 0.07 \mathrm{nmol} / \mathrm{l}($ mean $\pm \mathrm{SEM})$. At similar infusion rates, higher concentrations of proinsulin and the analogues were obtained due to 


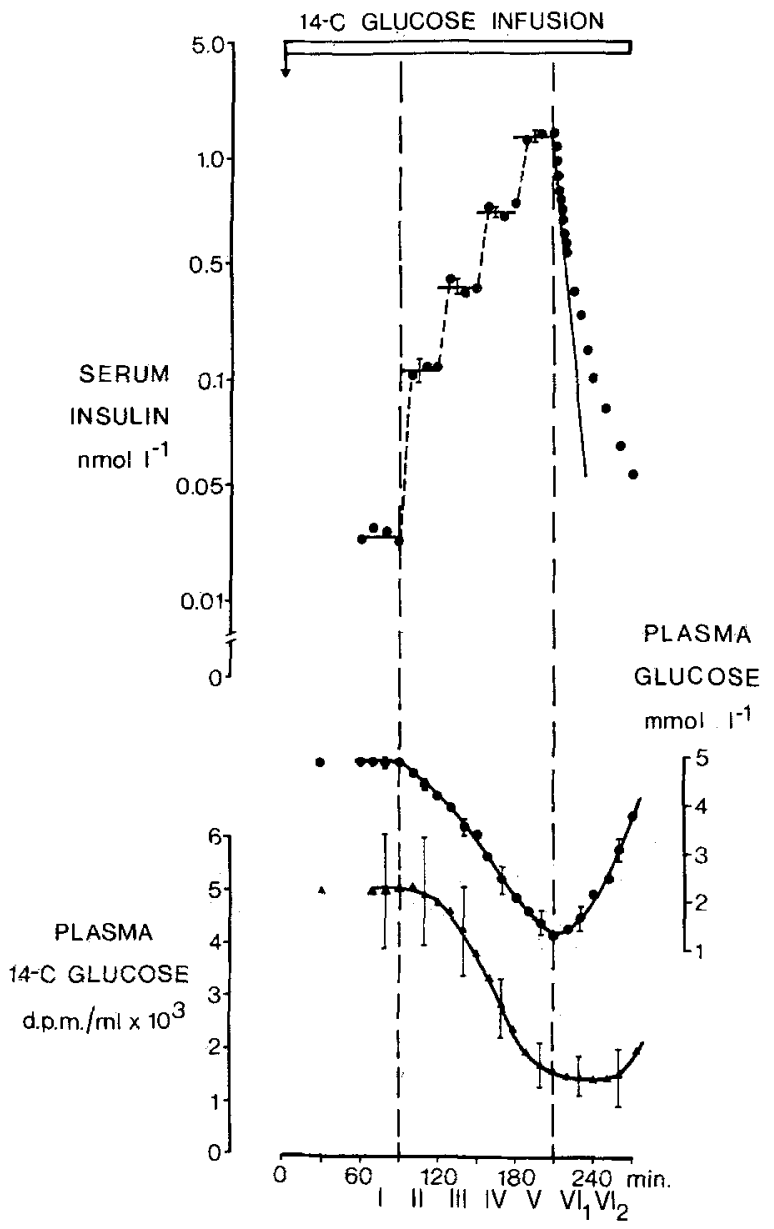

Fig. 1. Results from insulin infusion in six anaesthetised dogs showing insulin concentrations achieved, plasma glucose concentrations. $\Phi$ represents mean $=$ SF.M. $\left[{ }^{14} \mathrm{C}\right]$ glucose concentration $T$ mean \pm SEM. Period I was the control period; during periods II to $V$ there was a stepwisc increase in insulin infusion rate (sec methods section)

their slower metabolism [4], thesc results arc given in Table 1.

Both plasma glucose and $\left[{ }^{14} \mathrm{C}\right]$-glucose concentrations fell progressively in response to the insulin infusion. Figure 1 demonstrates that in period II insulin lowered plasma glucose concentration more markedly than $\left[{ }^{14} \mathrm{C}\right]$-glucose concentration indicating that the carliest detectable effect of insulin was inhibition of glucose production ( $\mathrm{Ra}$ ) by the liver. When the insulin infusion ceased, plasma glucose began to rise immediately whercas $\left[{ }^{14} \mathrm{C}\right]$-glucose ceased to fall but did not rise for forty minutes indicating rapid release of unlabelled glucose by the liver.

\section{Control Experiments}

Figure 2 shows mean results from four 'control' experiments. Plasma glucose concentration remained
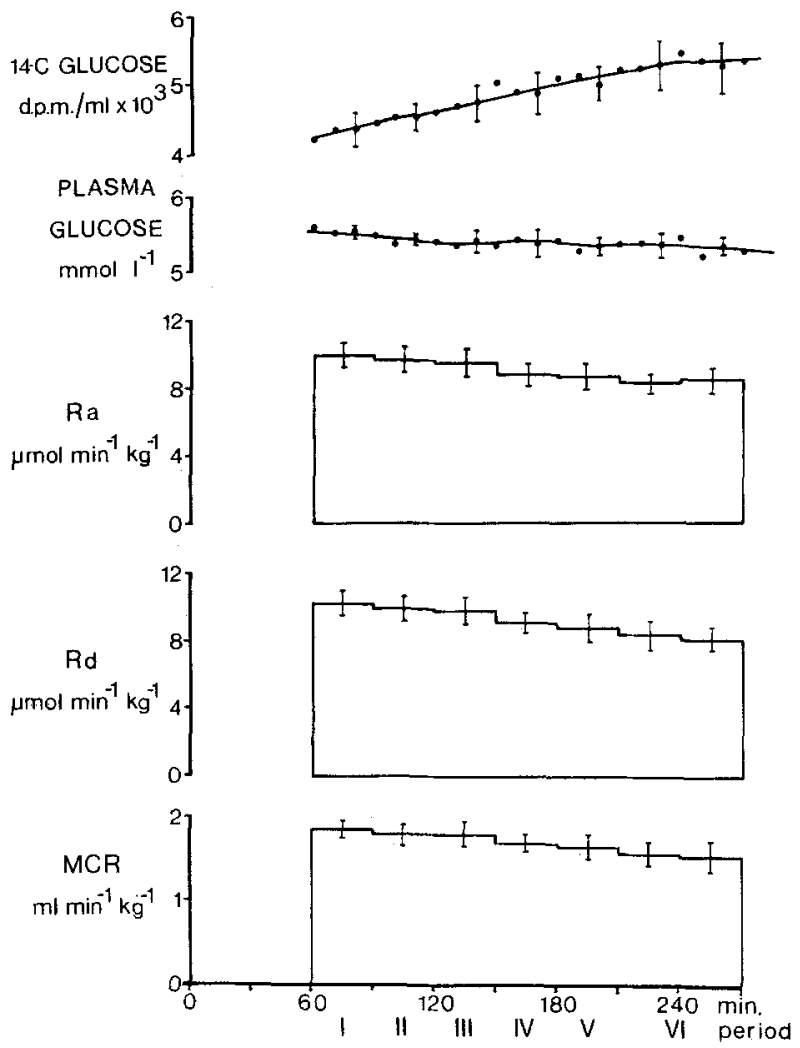

Fig. 2. Mean results from four control experiments (saline infusions) showing plasma glucose and $\left[{ }^{14} \mathrm{C}\right]$ glucose concentration and calculated rates of appcarance $(\mathrm{Ra})$, disappcarance $(\mathrm{Rd})$ and metabolic clearance rates (MCR) of glucose. Error bars indicate SEM. Other symbols as in Figure 1

constant at a mean of $5.4 \mathrm{mmol} / \mathrm{l}$ but $\left[{ }^{14} \mathrm{C}\right]$-glucose concentration increased slowly over the $270 \mathrm{~min}$. The calculated rates of glucose appearance $(\mathrm{Ra})$ and disappearance $(\mathrm{Rd})$ fell simultaneously from $10.1 \pm 0.7$ to $8.4 \pm 0.4 \mu \mathrm{mol} / \mathrm{min} / \mathrm{kg}$ (mean \pm SEM). Metabolic clearance rate also fell. This progressive fall in $\mathrm{Ra}$ and Rd seen in the control experiments (Figs. 2, 3) had to be taken into consideration when responses during peptide infusions were studied.

\section{Recycling of Glucose}

A mean value of $9 \%$ of the $\left[{ }^{14} \mathrm{C}\right]$ infused was recycled. This value was constant over the time course of the experiment and unaltered by insulin or analogue infusion. Since measurement of recycling was susceptible to considerable errors due to low count rates, results presented here have not been corrected. 

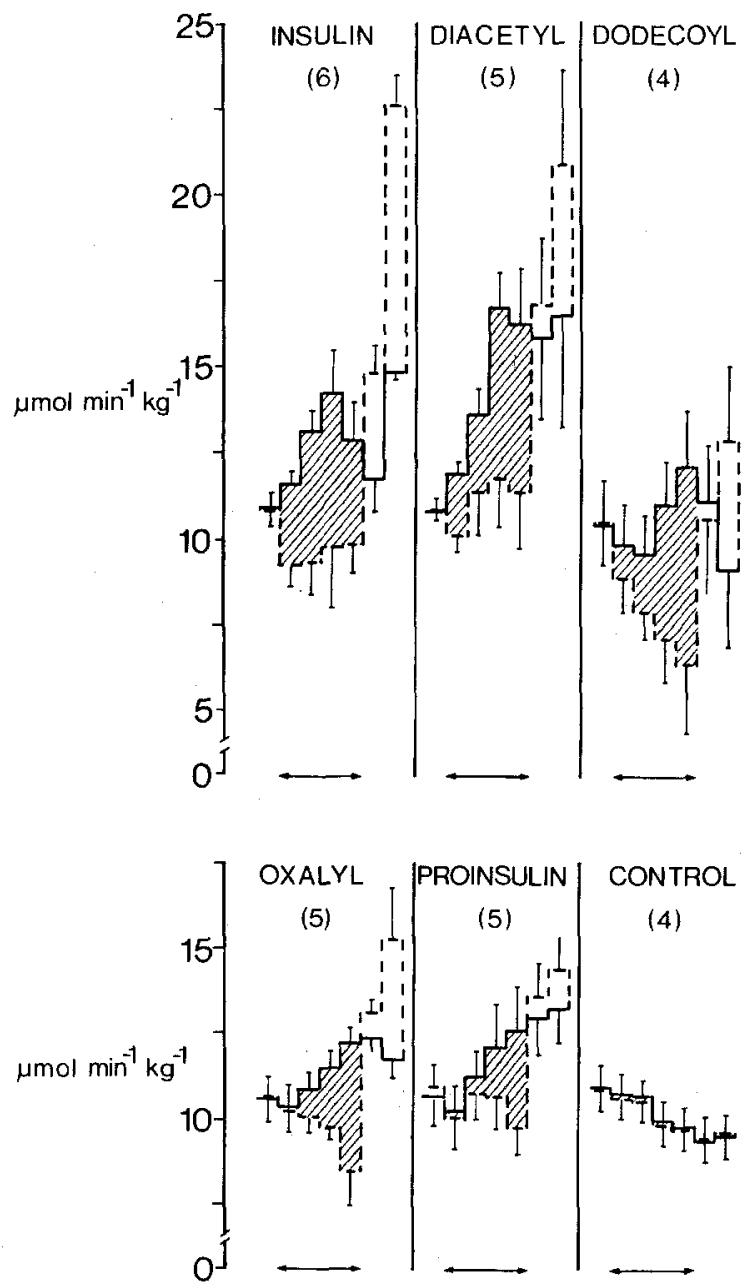

Fig. 3. Calculated rates plotted against time, of appearance $(\mathrm{Ra},---)$ ) and disappearance $(\mathrm{Rd},-\longrightarrow)$ of glucose during infusions of insulin, three semisynthetic insulin analogues and proinsulin and during control experiments. Numbers of experiments in each group are shown in parentheses. Error bars represent SEM; $\leftrightarrow$ represents infusion period i.e. $90-210 \mathrm{~min}$. Hatched areas indicate periods of falling glucose concentrations: i.e. $\mathrm{Ra}<\mathrm{Rd}$

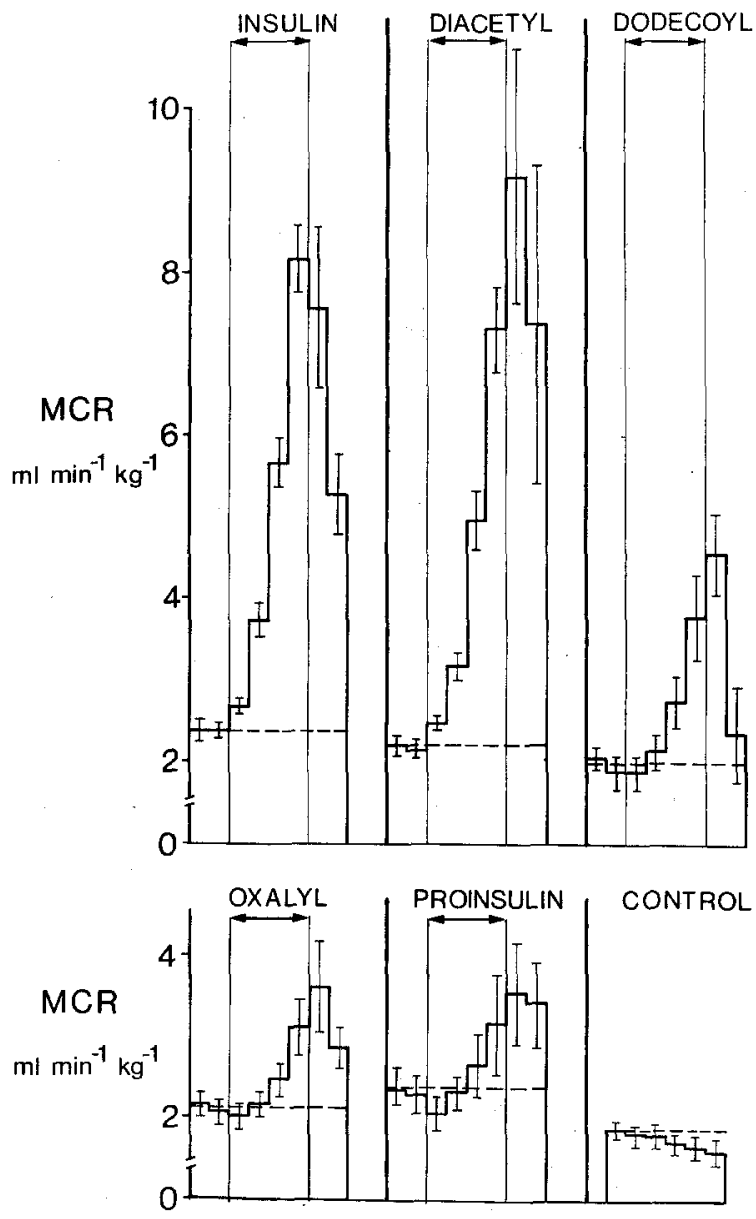

Fig. 5. Calculated metabolic clearance rates of glucose plotted against time during infusions of insulin, three semisynthetic insulin analogues, proinsulin and during control experiments. Numbers of experiments in each group are as in Figure 3. Error bars represent SEM: $\leftrightarrow$ represents infusion period i.e. $90-210 \mathrm{~min}$

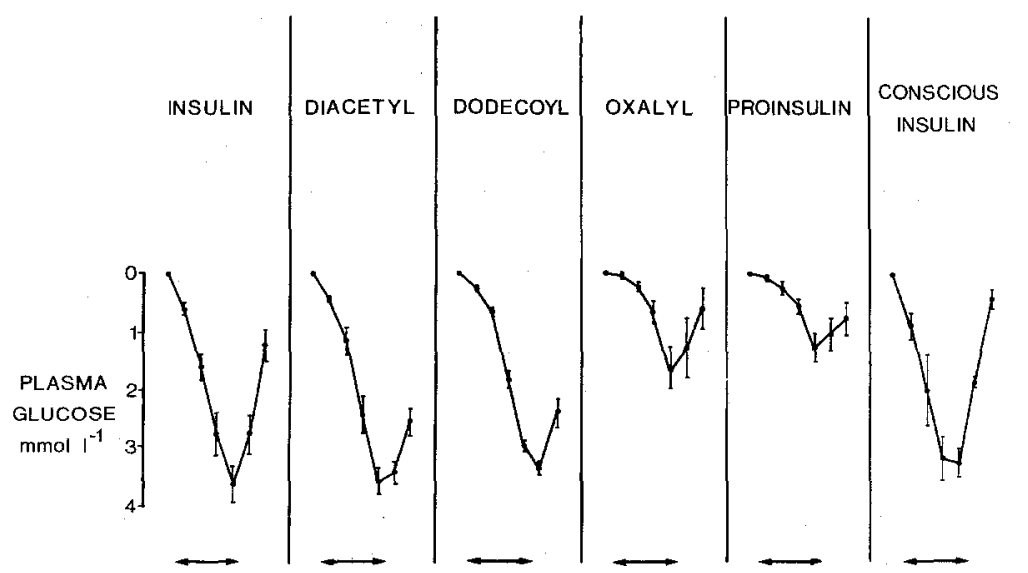

Fig. 4. Comparison of degree of hypoglycaemia induced by equimolar infusions of insulin, three semisynthetic insulin analogues and proinsulin. Fall in plasma glucose concentration from baseline is plotted against time. $\$$ represents mean \pm SEM $\leftrightarrow$ represents period of infusion from 90-210 min: "Conscious insulin" refers to insulin infusion in conscious dogs 

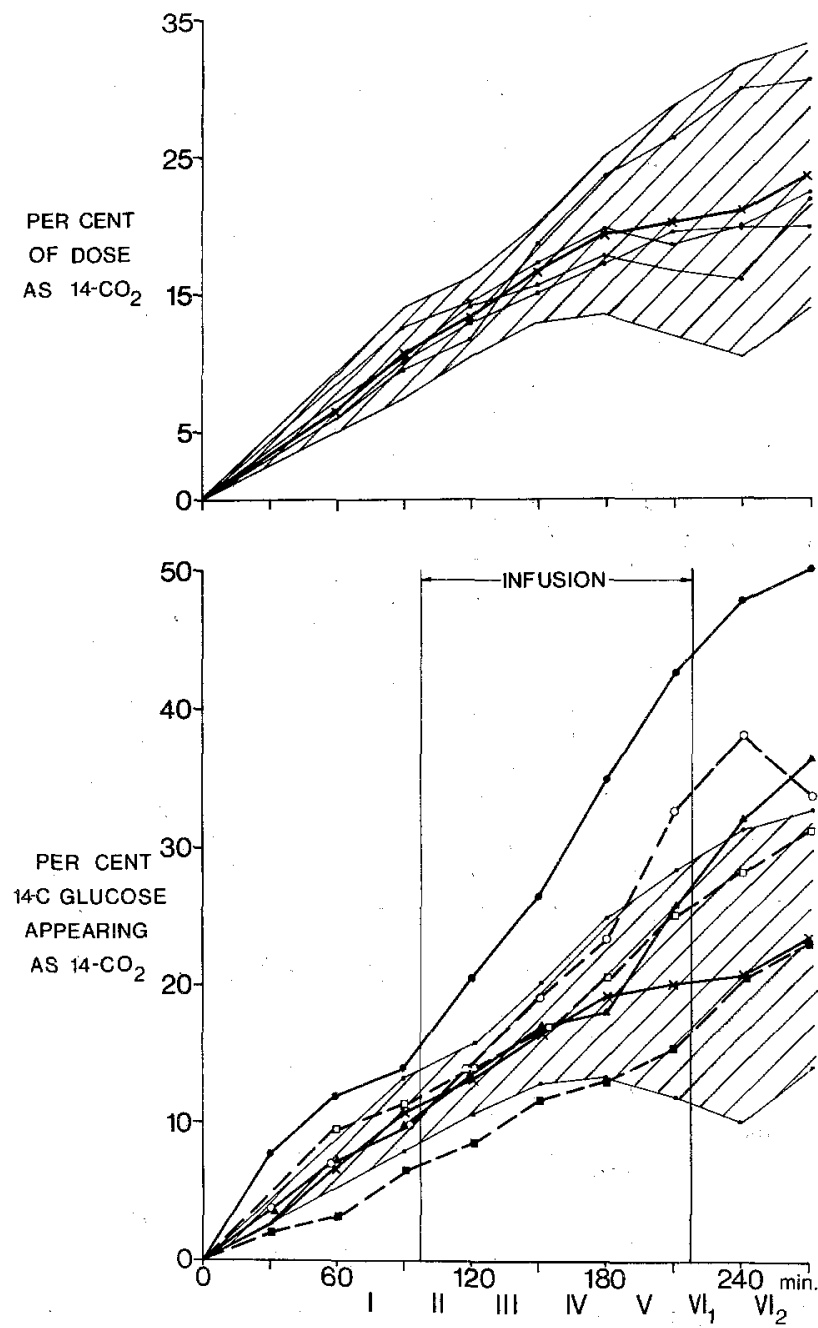

Fig. 6. ${ }^{14} \mathrm{CO}_{2}$ produced per minute is plotted as a percentage of $\left[{ }^{14} \mathrm{C}\right]$-glucose administered. The top graph shows results from four control experiments. The shaded area represents mean $\pm 2 \mathrm{SD}$. The bottom graph shows mean results from the five experimental infusion groups (insulin $\bullet$; diacetyl $\circ$, dodecoyl $\mathbf{E}$, oxalyl $\square$, insulins and proinsulin $\Delta$ ) superimposed on the control data

\section{Effects of Insulin on Glucose Turnover}

Figure 3 shows mean ( \pm SEM) rates of appearance (Ra), disappearance (Rd) and Figure 5, metabolic clearance rates (MCR) of glucose in each experimental group. Insulin results are shown at top left. In the steady state (Basal period I) $\mathrm{Ra}$ and $\mathrm{Rd}$ were equal at $11.4 \pm 0.5 \mu \mathrm{mol} / \mathrm{min} / \mathrm{kg}$. The initial effect of insulin was to cause a $16 \%$ fall in $\mathrm{Ra}$, which was statistically significant ( $p<0.05$; paired ' $t$ ' test), but no significant change in Rd. At higher insulin concentrations (periods III, IV) the depression in Ra was maintained and accompanied by a progressive stimulation of peripheral utilisation (Rd) to reach a maximum of $131 \%$ of its basal value in period IV. By period V plasma glucose concentration had fallen to hypoglycaemic values and there was no further rise in $\mathrm{Rd}$. When insulin infusion ceased (period VI) antihypoglycaemic mechanisms produced an immediate, large rise in $\mathrm{Ra}$ which reached a maximum of $213 \%$ of its basal value; $\mathrm{Rd}$ fell initially before rising in parallel with the rise in plasma glucose concentrations. Figure 5 demonstrates the 3.5 fold stimulation of glucose MCR by insulin ( $\mathrm{p}<0.01$ periods II and III; $\mathrm{p}<$ 0.001 periods $I V$ and $V$ ).

\section{Effect of Insulin Analogues on Glucose Turnover}

Figure 4 demonstrates that similar degrees of hypoglycaemia were achieved during insulin, diacetyl insulin and dodecoyl insulin experiments. However, equimolar infusions of oxalyl insulin and proinsulin produced a much smaller hypoglycaemic effect.

(a) Diacetyl Insulin. Diacetyl insulin caused no change in glucose Ra (Fig. 3). Hypoglycaemia was produced by a progressive stimulation of peripheral utilisation (Rd) up to $157 \%$ of its basal value (Rd was greater than in control experiments in all infusion periods, $\mathrm{p}<0.05-<0.001$ ). A rise in $\mathrm{Ra}$ (to $197 \%$ of its basal value) was again seen when the infusion was stopped. As with insulin the increase in $\mathrm{Rd}$ is further reflected in the four fold rise in MCR (Fig. 5).

(b) Crosslinked Analogues and Proinsulin. All three crosslinked peptides produced an initial fall in $\mathrm{Ra}$ (see Fig. 3) which was greater than at an equivalent time during control experiments (dodecoyl 16\% fall from basal $p<0.01$; proinsulin $13 \%$ fall from basal $\mathrm{p}<0.05$; oxalyl $8 \%$ fall from basal $\mathrm{p}<0.1>0.05$ ). Further depressions in $\mathrm{Ra}$ were produced as the serum concentration of crosslinked analogues and proinsulin increased. These were highly significant when related to baseline values in the case of dodecoyl insulin (periods II, III $\mathrm{p}<0.001$, IV $\mathrm{p}<$ 0.05 ; paired ' $\mathrm{t}$ ' test) and reached a maximum decrease of $59 \%$ of basal values in period $\mathrm{V}$.

There was little response of peripheral glucose uptake. Rd did not rise above baseline values until period IV. A small rise in Rd was seen in all three peptide groups in period $\mathrm{V}$ (dodecoyl $\mathrm{p}<0.1$ $>0.05$; oxalyl $p<0.05$; proinsulin $p<0.01$ compared with basal values). This minor effect of the crosslinked peptides on Rd is further emphasised by the greatly reduced effect of these materials on MCR (Fig. 5).

When the analogue infusions were stopped Ra rose. However, the rise was much less marked than that seen after the insulin infusion. 
The shaded areas in Figure 3 represent the development of hypoglycaemia ( $\mathrm{Rd}$ was greater than $\mathrm{Ra}$ ) and the unshaded areas the return to normoglycaemia ( $\mathrm{Ra}$ was greater than $\mathrm{Rd}$ ). It appeared that diacetyl insulin promoted hypoglycaemia mainly by increasing peripheral glucose utilisation (shading mainly above baseline) in contrast to dodecoyl insulin which caused the same degree of hypoglycaemia (Fig. 4) by preferentially decreasing production of glucose (shading mainly below baseline). Insulin exerted a combined effect. Oxalyl insulin and proinsulin appeared to behave more like dodecoyl insulin.

\section{Carbon Dioxide Production}

Figure 6 shows that a steady rise in percentage ${ }^{14} \mathrm{CO}_{2}$ production occurred in all groups including controls. Insulin and diacetyl insulin stimulated a significantly greater ${ }^{14} \mathrm{CO}_{2}$ production than occurred in control experiments in periods IV, $\mathrm{V}(\mathrm{p}<0.05)$ and $\mathrm{VI}(\mathrm{p}<$ $0.001)$ (insulin) and in periods $\mathrm{V}$ and VI $(\mathrm{p}<0.05)$ (diacetyl insulin). No other responses could be distinguished by statistical analysis from the control experiments.

\section{Insulin Infusions in Conscious Dogs}

The insulin infusions into conscious dogs produced four satisfactory steady state insulin concentrations. Plasma glucose responses (Fig. 4) were similar to the responses in anaesthetised dogs except that the plasma glucose returned more rapidly to fasting concentrations when the insulin infusion ceased. The effects of insulin were similar in conscious and anaesthetised dogs. There was a tendency for $\mathrm{Ra}$ to be inhibited more completely in the conscious animals in the early part of the experiment. Anti-hypoglycaemic responses stimulated $R a$ to return to baseline values during the highest rate of insulin infusion (period $\mathrm{V}$ ). This was associated with a more rapid increase in $\mathrm{Ra}$ and consequently a more rapid rebound in plasma glucose concentration towards baseline values when the insulin infusion was stopped.

\section{Discussion}

Tracer techniques have been widely used to investigate the mechanism by which insulin influences plasma glucose levels. In the fasting animal glucose concentration is a function of glucose entry into plasma from the liver and its removal from the plasma by peripheral tissues [7]. This was demonstrated using hepatic vein catheterization by Madison et al. [17] and more recently by Harding et al. [18].
Steele $[9,12]$ described a tracer infusion method which allowed measurement of the glucose fluxes through these two pathways and also enabled these measurements to be made in the non-steady state without the need to insert catheters across the liver and other tissues. We have used this method to compare the effects of insulin with those of three semisynthetic analogues of insulin and of proinsulin. Results from the four control experiments suggest that glucose turnover progressively decreased over the course of the five hour experiment, probably due to the continuing prolonged fast [20].

The influence of insulin and its analogues on ${ }^{14} \mathrm{CO}_{2}$ production could be considered as a "tissue assay" in vivo. The time lag between tissue hormone action and ${ }^{14} \mathrm{CO}_{2}$ production is attributed to the slow turnover times of the bicarbonate and triglyceride pools in the body [19]. Insulin increased ${ }^{14} \mathrm{CO}_{2}$ production above "control" values from the start of its infusion as did diacetyl insulin at high serum concentrations. This demonstrates that these substances not only increased tissue uptake of glucose but also stimulated glucose oxidation by the tissues. No increased tissue metabolism was observed with the crosslinked analogues and proinsulin.

Insulin produced an initial reduction in hepatic glucose output ( $\mathrm{Ra})$. At higher insulin concentrations $\mathrm{Ra}$ remained low and hypoglycaemia was brought about by a combination of decreased glucose production and increased peripheral utilisation (Rd). Compensating mechanisms to combat hypoglycaemia later modified this pattern. Similar results have been reported by Issekutz et al. [21] in diabetic dogs and more recently by Brown et al. [22] in diabetic human subjects. These workers found that low insulin infusion rates affected only hepatic glucose production whereas at higher infusion rates both production and utilisation were affected. In our experiments, at the high insulin concentrations achieved in periods IV and $V$, hypoglycaemia was induced causing both a fall in $\mathrm{Rd}$ and a rise in $\mathrm{Ra}$.

Experiments where hypoglycaemia was prevented by glucose infusion have shown that insulin progressively stimulated peripheral glucose uptake and lowered glucose production $[5,23]$. Hypoglycaemia leads to the secretion of counter-regulatory hormones which are known to act by increasing glucose production $(\mathrm{Ra})$, these include catecholamines [24], glucagon [25] and growth hormone [26]. It has also been suggested that they may inhibit glucose uptake (Rd) directly [5, 27].

The structural analogues of insulin studied in this paper appeared to fall into three patterns in terms of their effects on glucose metabolism. Diacetyl insulin (where the free amino groups at $A_{1}$ und $B_{29}$ are mod- 
ified by addition of acetyl groups) produced a similar degree of hypoglycaemia as insulin. It acted by increasing peripheral glucose utilisation in a manner that was indistinghishable from the native hormone.

Dodecoyl insulin (containing a crosslink between $\mathrm{A}_{1}$ and $\mathrm{B}_{29}$ ), which also produced a similar amount of hypoglycaemia to insulin, seemed to act preferentially on the liver. It inhibited glucose production progressively but had little action on peripheral utilisation. Although stimulation of $\mathrm{Rd}$ in period $\mathrm{V}$ was very small, the slight rise in MCR, that is the maintainance of Rd during a period of falling plasma glucose concentration, indicates some peripheral insulin-like effect. The relatively greater effect of this analogue on $\mathrm{Ra}$ than $\mathrm{Rd}$ could contribute to the discrepancy in its biological potency measured in vivo and in vitro ( $16 \%$ vs $7 \%$ that of insulin) [4]. If its primary action was on the liver it would be expected to be less potent when tested in the isolated fat cell. Binding studies with dodecoyl insulin do not suggest a higher affinity for the hepatic insulin receptors [4] so such primacy in vivo would depend on differences of local distribution and/or metabolism, or possibly on differences in post-receptor events.

The responses to proinsulin (containing a peptide chain linking $A_{1}$ and $B_{30}$ ) and oxalyl insulin (crosslinked between $A_{1}$ and $B_{29}$ ) are less well defined. They appeared to exert more effect on Ra than Rd in a similar manner to dodecoyl insulin. However, if comparisons are made at similar levels of hypoglycaemia (ie high analogue and low insulin concentrations) then oxalyl insulin and proinsulin stimulate $\mathrm{Rd}$ and inhibit $\mathrm{Ra}$ in a manner very similar to insulin.

The observation that specific chemical modification of the insulin molecule can result in qualitative differences in the biological effect in the intact animal is of importance. It suggests the possibility that different tissues have subtle differences in their specificities for the insulin molecule. In vivo not only the binding affinity and capacity of cell surface receptors but also differences in distribution and metabolism will influence the effectiveness of an insulin analogue on a particular tissue. The materials studied so far are metabolised more slowly than insulin [4] and therefore higher serum concentrations (and probably tissue concentrations) occur at comparable doses. The ratio of receptor and degrading activities for insulin varies in different tissues. Liver, fat and muscle are all sensitive to insulin, but hepatic degradation is more rapid than in the peripheral tissues. An analogue protected to some extent from degradation by liver enzymes may remain longer at the cell surface and produce a proportionally greater action. That this could apply to $A_{1}-B_{29}$ crosslinked insulins is supported by the observation that these materials have low susceptibility to the enzyme glutathioneinsulin transhydrogenase [28].

Chemically modified insulins may be important not only in the investigation of the action and metabolism of insulin, but also in the treatment of diabetes. Endogenous insulin enters the portal circulation and proceeds directly to the liver whereas insulin used therapeutically is of necessity administered systemically. It is possible that a suitable chemically modified insulin could be developed which because of its proportionally greater central hepatic action would when peripherally administered act in a more physiological manner than insulin itself.

Acknowledgements. The authors would like to thank the British Diabetic Association, The Wellcome Trust and the Research (Endowments) Committee of St Thomas' Hospital for invaluable financial support, and Jane Collins and Hilary Cox for their tolerant and efficient secretarial assistance.

\section{References}

1. Brandenburg D, Busse W, Gattner $\mathrm{H}$, Zahn $\mathrm{H}$, Wollmer A, Gliemann J, Puls W (1973) Structure-function studies with chemically modified insulins. In: Hanson $H$, Jakubke HD (eds) Peptides 1972, Proceedings of the Twelfth European Peptide Symposium, Reinhardstrunn Castle, GDR. North Holland Publishing Company, Amsterdam, pp 270-283

2. Freychet P, Brandenburg D, Wollmer A (1974) Receptorbinding assay of chemically modified insulins. Comparison with in vitro and in vivo bioassays. Diabetologia 10: 1-5

3. Blundell TL, Dodson GG, Dodson E, Hodgkin DC, Vyayan M (1971) X-ray analysis and the structure of insulin. Recent Prog Horm Res 27: 1-40

4. Jones RH, Dron DI, Ellis MJ, Sönksen PH, Brandenburg D (1976) Biological properties of chemically modified insulins. I. Biological activity of proinsulin and insulin modified at $\mathbf{A}_{1}$ glycine and $B_{29}$-lysine. Diabetologia 12: 601-608

5. de Bodo RC, Steele R, Altszuler N, Dunn A, Bishop JS (1963) On the hormonal regulation of carbohydrate metabolism; studies with ${ }^{14} \mathrm{C}$ glucose. Recent Prog Horm Res 19: 445-488

6. Hetenyi G Jr, Wrenshall GA, Best CH (1961) Rates of production, utilisation, accumulation and apparent distribution space of glucose. Effects of insulin in dogs using a validated tracer method. Diabetes 10: 304-311

7. Hetenyi G Jr (1971) The regulation of glucose production and utilisation in the intact animal. Acta Diabetol Lat [Suppl] 8: 213-227

8. Vranic M, Wrenshall GA (1968) Matched rates of insulin infusion and secretion and concurrent tracer - determined rates of glucose appearance and disappearance in fasting dogs. Can J Physiol Pharmacol 46: 383-390

9. Steele R, Wall JS, de Bodo RC, Altszuler N (1956) Measurement of size and turnover rate of the body glucose pool by the isotope dilution method. Am J Physiol 187: 15-24

10. Dunn DF, Friedmann B, Maass AR, Reichard GA, Weinhouse S (1957) Effects of insulin on blood glucose entry and removal rates in normal dogs. J Biol Chem 225: 225-237

11. Somogyi M (1945) Determination of blood sugar. J Biol Chem 160: 68-73

12. Steele R (1959) Influences of glucose loading and of injected insulin on hepatic glucose output. Ann NY Acad Sci 82: 420-430 
13. Cowan JS, Hetenyi G Jr (1971) Glucoregulatory responses in normal and diabetic dogs recorded by a new tracer method. Metabolism 20: 360-372

14. Sönksen PH, Tompkins CV, Srivastava MC, Nabarro JDN (1973) A comparative study of the metabolism of human insulin and procine proinsulin in man. Clin Sci Mol Med 45: 633-654

15. Katz J, Dunn A (1967) Glucose-2-t as a tracer for glucose metabolism. Biochemistry 6: 1-5

16. Issekutz BJR, Allen M, Borkow I (1972) Estimation of glucose turnover in the dog with glucose-2-t and glucose- $\mathrm{U}^{14} \mathrm{C}$. Am J Physiol 222: 710-712

17. Madison LL, Combes B, Adams R, Strickland W (1960) The physiological significance of the secretion of endogenous insulin into the portal circulation. III. Evidence for a direct immediate effect of insulin on the balance of glucose across the liver. J Clin Invest 39: 507-522

18. Harding PE, Bloom G, Field JB (1975) Effect of infusion of insulin into portal vein on hepatic extraction of insulin in anaesthetised dogs. Am J Physiol 228: 1580-1588

19. Bolinger RE, Schafer ME, Kuske TT (1966) Effect of prolonged fasting on the expired ${ }^{14} \mathrm{CO}_{2}$ from palmitate and glucose in obese subjects. Metabolism 15: 394-400

20. Cowan JS, Vranic M, Wrenshall GA (1969) Effects of preceding diet and fasting on glucose turnover in normal dogs. Metabolism 18: 319-330

21. Issekutz BJr, Issekutz TB, Elahi D, Borkow I (1974) Effect of insulin infusions on the glucose kinetics in alloxan-streptozotocin diabetic dogs. Diabetologia 10: 323-328

22. Brown PM, Tompkins CV, Juul S, Sönksen PH (1978) Mechanism of the action of insulin in diabetic patients; a dose related effect on glucose production and utilisation. $\mathrm{Br}$ Med $\mathrm{J}$ I: $1239-1242$

23. Steele R, Bishop JS, Dunn A, Altszuler N, Rathgeb I, de Bodo RC (1965) Inhibition by insulin of hepatic glucose production in the normal dog. Am J Physiol 208: 301-306

24. Garber AJ, Cryer PE, Santiago JV, Haymond MW, Pagliara AS, Kipnis DM (1976) The role of adrenergic mechanisms in the substrate and hormonal response to insulin-induced hypoglycaemia in man. J Clin Invest 58: 7-15

25. Cherrington AD, Vranic M (1974) Effect of interaction between insulin and glucagon on glucose turnover and FFA concentration in normal and depancreatised dogs. Metabolism 23: $729-744$

26. Cheng JS, Kalant N (1970) Effects of insulin and growth hormone on the flux rates of plasma glucose and plasma free fatty acids in man. J Clin Endocrinol Metab 31: 647-653

27. Fineberg SE, Merimee TJ (1974) Acute metabolic effects of human growth hormone. Diabetes 23: 499-504

28. Papachristodoulou P, Brandenburg D, Dron DI, Jones RH, Sönksen PH, Thomas JH (1977) Studies on the relationship between the molecular structure and the catabolism of insulin. Acta Biol Med Germ 36: 1705-1712

Received: October 9, 1978,

and in revised form: August 1, 1980

Dr. R. H. Jones

Department of Medicine

St. Thomas' Hospital Medical School

London SE1 7EH

England 